\title{
PENDEKATAN LEAN MANUFACTURING SEBAGAI USULAN UNTUK MEMINIMALKAN WASTE PADA PROSES PRODUKSI KAYU DECKING
}

\author{
(Studi Kasus : Perusahaan Pengolahan Kayu di Lamongan)
}

\author{
Ahmad Rido $\mathrm{M}^{1}$, Said Salim Dahda ${ }^{2}$, Elly Ismiyah ${ }^{3}$ \\ Program Studi Teknik Industri Fakultas Teknik Universitas Muhammadiyah \\ Gresik \\ *Email : ahmadrido01@gmail.com
}

\begin{abstract}
Abstrak Perusahaan Pengolahan kayu mentah merupakan perusahaan manufaktur yang menghasilkan produk olahan berupa kayu decking yang digunakan untuk lantai out dor . Dalam proses produksinya perusahaan mengalami kendala berupa masih adanya waste diantarnya adanya produk defect yang berimbas pada tidak tercapainya target output produksi dengan kriteria good quality. Dari permasalahan yang terjadi maka bagaimana mengidentifikasi dan memberikan usulan untuk mengurangi pemborosan (Waste) pada lantai produksi. Pedekatan yang digunakan terkait permasalahan yang terjadi di perusahaan ialah Lean Manufacturing, dengan penggambaran Value Stream Mapping. Ientifikasi pemborosan dilakukan dengan kuisioner kemudian hasil pembobotan waste diolah dengan tabel VALSAT. Dari hasil identifikasi didapat bobot waste defect $(4,2)$ uncessasry inventory $(3,9)$, waiting $(3,3)$ excessive transportation $(3,1)$ dan uncessary motion $(3,0)$. Hasil dari tabel VALSAT adalah tools Proses Activity Mapping (110,5), Supply Chain Response Matrix $(76,8)$ dan Quality Filter Mapping $(47,8)$ setelah itu Future Stare Mapping dan Failure Mode and Effcet Analysis dengan nilai RPN tertinggi yang akan diberikan usulan. Pemborosan (waste) dengan nilai RPN tertinggi untuk masing-masing waste, excessive transportation dengan penataan ulang tata letak, defect rework dengan pembekalan operator (breafing) dan monitoring, waitting dengan penambahan operator, unsesary motion dengan kaizen activity dan unsesary inventory dengan pengolahan defect rwork se-segera mungkin.
\end{abstract}

\section{Kata kunci : Lean Manufacturing, Seven Waste,Current State Value Stream Mapping, Value Stream Mapping Tolls VALSAT, Future Value Stream Mapping, FMEA}

\section{PENDAHULUAN}

Perusahaan Pengolahan Kayu mentah di lamongan merupakan salah satu perusahaan manufaktur yang bergerak dalam bidang pengolahan kayu. Perusahaan ini berdiri sejak tahun 2018 dan berlokasi di kota Lamongan, Jawa Timur. Produk dari perusahaan ini adalah kayu decking. Kayu Decking merupakan kayu yang digunakan untuk lantai outdoor rumah dimana kayu ini memiliki keunggulan berupa pola bergelombang dibagian atas sehingga tidak licin pada saat dipijak. Produk decking yang dihasilkan oleh perusahaan ini diperuntukan untuk komoditas ekspor, ini dikarenakan pasar yang menjanjikan dan sebagian besar konsumen berasal dari luar negeri.

Dalam proses produksi, perusahaan berusaha untuk menghasilkan produk dengan kualitas tinggi, sebagai salah satu keunggulan dan juga jaminan bagi para konsumennya akan produk yang dihasilkan perusahaan. Pada kenyataannya masih terdapat beberapa permasalahan yang terjadi pada proses produksi sehingga mempengaruhi kualitas dan juga performa perusahaan. Diantaranya adalah permasalahan karena 
timbulnya waste berupa defect yang terjadi pada proses produksi di perusahaan. Defect yang terjadi pada perusahaan dibagi menjadi 2 yaitu defect yang bisa di rework atau digunakan kembali dan reject (dibuang) karena tidak bisa digunakan kembali. Defect (kecacatan) jenis rework adalah kecacatan yang masih bisa ditoleransi oleh perusahaan karena masih bisa digunakan kembali, kecacatan jenis ini didominasi oleh ukuran tebal atau lebar produk yang tidak sesuai dengan spesifikasi yang telah ditentukan.

Rekapan jumlah produksi perusahaan dapat dilihat pada tabel dibawah ini :

Tabel 1 Jumlah Produksi

\begin{tabular}{|c|c|c|c|c|c|c|}
\hline \multirow[b]{2}{*}{ No } & \multirow[b]{2}{*}{ Bulan } & \multirow{2}{*}{$\begin{array}{c}\text { Total } \\
\text { Produksi } \\
(\mathrm{M} 3)\end{array}$} & \multirow{2}{*}{$\begin{array}{c}\text { Good } \\
\text { Quality } \\
\text { (M3) }\end{array}$} & \multicolumn{2}{|c|}{ Jenis Kecacatan } & \multirow{2}{*}{\begin{tabular}{|c} 
Total \\
Kecacatan \\
$(\mathrm{MB})$
\end{tabular}} \\
\hline & & & & $\begin{array}{l}\text { Rework } \\
\text { (M3) }\end{array}$ & $\begin{array}{l}\text { Reject } \\
\text { (MB) }\end{array}$ & \\
\hline 1 & Nov-2018 & 36,8814 & 23.5100 & 13,0869 & 0,2845 & 13,3714 \\
\hline 2 & Des-2018 & 14,8830 & 7.8008 & 6,74430 & 0,3379 & 7,0822 \\
\hline 3 & $\operatorname{Jan}-2019$ & 69,8044 & 58.4646 & 10,4116 & 0,9282 & 11,3398 \\
\hline 4 & Feb-2019 & 44,0459 & 37.8910 & 6,1294 & 0,0255 & 6,1549 \\
\hline
\end{tabular}

(Sumber : Data Perusaahan Pengolahan

Kayu )

Jika dipersentasekan data dari rekapan jumlah produksi tabel 1 jumlah produk good quality, rework dan reject dapat dilihat pada tabel dibawah ini :

Tabel 2 Persentase Produk Good Quality,

\begin{tabular}{|c|c|c|c|c|c|}
\hline & & \multirow{3}{*}{ Total Produlusi } & \multirow{3}{*}{$\begin{array}{l}\text { an Re } \\
\text { Good } \\
\text { Quality }\end{array}$} & \multirow{2}{*}{\multicolumn{2}{|c|}{ Jenis Cacat }} \\
\hline \multirow{2}{*}{$\mathrm{Ne}$} & \multirow{2}{*}{ Bulan } & & & & \\
\hline & & & & Retwork & Reject \\
\hline 1 & Nov-2018 & $36,8814 \mathrm{M} 3$ & $64 \%$ & $35 \%$ & $1 \%$ \\
\hline 2 & Des - 2018 & $14,8830 \mathrm{M3}$ & $52 \%$ & $45 \%$ & $2 \%$ \\
\hline 3 & \begin{tabular}{|l|l|} 
ann-2019 \\
\end{tabular} & $69,8044 \mathrm{M} 3$ & $84 \%$ & $15 \%$ & $1 \%$ \\
\hline 4 & Feb-2019 & $44,0459 \mathrm{M3}$ & $86 \%$ & $14 \%$ & $0 \%$ \\
\hline & Rata & & $71 \%$ & $27 \%$ & $1 \%$ \\
\hline
\end{tabular}

(Sumber : Data Perusaahan Pengolahan

$$
\text { Kayu) }
$$

Hasil dari wawancara dengan pihak perusahaan yaitu Bpk Didik selaku Kabag produksi mengatakan bahwa perusahaan menargetkan $80 \%$ dari total produksi perusahaan akan masuk kedalam kategori good quality mengingat perusahaan berfokus pada ekspor keluar negeri, namun seperti yang terlihat pada tabel 2 masih terdapat target yang tidak terpenuhi dan juga prosentase rework dan reject yang masih ada dengan presentase rework yang cukup tinggi, perusahaan memiliki toleransi rework sebesar $15 \%$ sedangkan untuk reject sebesar 5\%. Dari tabel 1.2 dapat diambil kesimpulan bahwa waste kecacatan produk dengan jenis rework melebihi batas toleransi yang diberikan perusahaan yakni sebesar $15 \%$. Waste defect dengan jenis Rework yang terjadi diperusahaan juga berimbas pada terjadinya waste berupa Penyimpanan yang tidak diperlukan (Unnecessary Inventory), ini dikarenakan rework yang terjadi tidak langsung diproses melainkan akan disimpan untuk digunakan kembali untuk order dari customer selajutnya bila spesifikasi produk yang dipesan memungkinkan untuk memakai bahan rework dari proses produksi sebelumnya. Besaran Unnecessary Inventory dapat dilihat pada tabel 3 dibawah ini

Tabel 3 Besaran Unnecessary Inventory dari rework di Perusahaan

\begin{tabular}{|c|c|c|}
\hline No & Bulan & Jumlah (M3) \\
\hline 1 & Nov - 2018 & 13,0869 \\
\hline 2 & Des - 2018 & 6,74430 \\
\hline 3 & Jan - 2019 & 10,4116 \\
\hline 4 & Feb - 2019 & 6,1294 \\
\hline
\end{tabular}

(Sumber : Data Perusaahan Pengolahan Kayu)

Selaian waste berupa defect dan Unnecessary Inventory perusahaan juga memiliki waste waiting dari kegiatan maintenance perusahaan. Kegiatan maintenance yang tidak terjadwal (Corrective Maintenance) dilakukan setelah mesin atau fasilitas produksi mengalami kerusakan sehingga tidak dapat berfungsi dengan baik, maintenance yang dilakukan berupa pergantian komponen pada mesin. Berikut adalah data maintenance yang dilakukan perusahaan : 
Tabel 4 Data maintenance mesin produksi Pada Bulan Oktober 2018 -

Februari 2019

\begin{tabular}{|c|c|c|c|}
\hline No & Jenis Mesin & Jenis Kerusakan & $\begin{array}{l}\text { Jumlah } \\
\text { (Kali) }\end{array}$ \\
\hline \multirow{3}{*}{1} & \multirow{3}{*}{ SawMill } & Brush (Sikat) & 2 \\
\hline & & Rotor & 1 \\
\hline & & Main Shaft & 1 \\
\hline \multirow{3}{*}{2} & \multirow{3}{*}{ Mesin Scrup } & Bearing & 1 \\
\hline & & Gear & 2 \\
\hline & & pulley & 1 \\
\hline \multirow{2}{*}{3} & \multirow{2}{*}{ Mesin Potong } & Rotor & 1 \\
\hline & & Brush (sikat) & 2 \\
\hline \multirow{3}{*}{4} & \multirow{3}{*}{ Band Saw } & Bearing & 2 \\
\hline & & pulley & 1 \\
\hline & & fanbelt & 1 \\
\hline \multirow{4}{*}{5} & \multirow{4}{*}{ Mesin Mollding } & Brush (Sikat) & 3 \\
\hline & & Fanbelt & 2 \\
\hline & & Gear & 2 \\
\hline & & Bearing & 1 \\
\hline & \multicolumn{2}{|c|}{ Total } & 22 \\
\hline
\end{tabular}

(Sumber : Data Perusaahan Pengolahan Kayu)

Tabel 5 Rekap jumlah waktu pengerjaan (Downtime) dari Maintenence

\begin{tabular}{|c|c|c|c|c|c|}
\hline No & Jenis Mesin & Jenis Kerusakran & Janlah & $\begin{array}{c}\text { Lama } \\
\text { Pengerjaan }\end{array}$ & $\begin{array}{l}\text { Total } \\
\text { (Memil) }\end{array}$ \\
\hline \multirow{3}{*}{1} & \multirow{3}{*}{ SamMill } & Bruh (Sikat) & 2 & 60 & 120 \\
\hline & & Retext & 1 & 90 & 90 \\
\hline & & Main Sbaft & 1 & 90 & 90 \\
\hline \multirow{3}{*}{2} & \multirow{3}{*}{ Mesin Scrup } & Bearing & 1 & 60 & 80 \\
\hline & & Gear & 2 & 45 & 90 \\
\hline & & pulley & 1 & 45 & 45 \\
\hline \multirow{2}{*}{3} & \multirow{2}{*}{ Mean Potong } & Rotore & I & 90 & 90 \\
\hline & & Bnokh (nikat) & 2 & 60 & 120 \\
\hline \multirow{3}{*}{4} & \multirow{3}{*}{ Band Saw } & Bearing & 2 & 60 & 120 \\
\hline & & vulley & 1 & 45 & 45 \\
\hline & & fanbelt & 1 & 30 & 30 \\
\hline \multirow{4}{*}{5} & \multirow{4}{*}{ Mesin Molliting } & Brush (Sikat) & 3 & 60 & 180 \\
\hline & & Fanbelt & 2 & 30 & 60 \\
\hline & & Gear & 2 & 45 & 90 \\
\hline & & Beaning & 1 & 60 & 60 \\
\hline & \multicolumn{4}{|c|}{ Total } & 1335 \\
\hline
\end{tabular}

(Sumber : Data Perusaahan Pengolahan Kayu)
Dari tabel 4 diatas dapat diketahui selama bulan November 2017 sampai bulan Februari 2018 terdapat total 24 kerusakan (Maintenance) pada mesin produksi di perusahaan. Dari total 24 perbaikan (maintenance) yang dilakukan perusahaan menhasilkan downtime dari lama pengerjaan tiap perbaikan pada mesin yang mengalami kerusakan dengan total waktu 1.335 menit untuk total waktu perbaikan yang dapat dilihat pada tabel 5 Berdasarkan data-data yang terkumpul dari perusahaan terjadi pemborosan yang terjadi diperusahaan yaitu waste defect yang berimbas pada adanya penyimpanan yang tidak perlu (Unnecessary Inventory) berupa penumpukan bahan digudang yang seharusnya bahan tersebut jika lolos Quality Control tidak akan ditumpuk lagi digudang, waste downtime yang menyebabkan waktu tunggu (Waiting) dikarenakan maintenance yang terjadi pada saat produksi berlangsung. Tetapi tidak menutup kemungkinan terjadi pemborosan lain di perusahaan seperti Over Production, Innappropriate Processsing, Excessive Transportation dan Unccessary Motion. Untuk mengatasi permasalahan yang terjadi supaya tercapainya peningkatan sisi kualitas dan sistem produksi. Diperlukan metode untuk dapat mrngidentifikasi dan menganalisa waste yang terjadi, salah satu alat atau metode yang dapat diterapkan diperusahaan adalah lean menufacturing. Lean Manufacturing merupakan metode yang sesuai untuk mengoptimalkan performasi dari system dan proses produksi karena mampu mengidentifikasi, mengatur menganalisa dan mencari solusi perbaikan atau meningkatkan performansi secara komprehensif. Penerapan lean berfokus pada meningkatkan efisien tanpa mengurangi efekifitas proses diantaranya peningkatan operasi yang value added, mereduksi pemborosan (waste) dan memenuhi kebutuhan customer, konsep lean diterapkan mengeliminasi waste pada value stream system dirumuskan (Hines \& Taylor 2000).

Untuk mendukung penelitian ini selain Lean Manufacturing juga menggunakan Tools yang digunakan sebagai usulan 
perbaikan yaitu Failure Mode and Effects Analysis (FMEA). Failure Mode and Effects Analysis (FMEA) adalah metodeologi yang merancang untuk mengidentifikasi mode kegagalan potensial pada suatu produk atau proses sebelum terjadi, mempertimbangkan resiko yang berkaitan dengan mode kegagalan tersebut, mengidentifikasi serta melaksanakan tindakan korektif untuk mengatasi masalah yang paling pnting (Puspita dkk, 2014). Suatu mode kegagalan adalah apa saja yang termasuk dalam kecacatan atau kegagalan dalam desain, kondisi luar batas spesifikasi yang telah ditetapkan atau perusahaan dalam produk yang menyebabkan terganggunya fungsi dari produk itu sendiri. Dengan menghilangkan mode kegagalan, maka FMEA akan meningkatkan keandalan dari produk sehingga meningkatkan kepuasan pelanggan yang menggunakan produk tersebut.

\section{METODE}

\section{Lean Manufacturing}

Lean dapat didefinisikan sebagai suatu pendekatan sistemik dan sistematik untuk mengidentifikasi dan menghilangkan pemborosan (waste) atau aktivitas-aktivitas yang tidak bernilai tambah (Non Value Adding Activities) melalui peningkatan terus menerus secara radikal dengan cara mengalirkan produk (material, work in process, output) dan informasi menggunakan pull system dari pelanggan internal dan eksternal untuk mengejar keunggulan dan kesempurnaan. (Gaspersz \& Avanti, 2011) Menurut Field (2001) Berikut ini adalah definisi dasar dari masing-masing Lima Elemen Utama:

1. Manufacturing

2. Organisasi

3. Kontrol Proses

4. Metrik

5. Logistik

Lean manufacturing adalah semua yang berkaitan reduksi waste, perbaikan yang terus menerus dan meningkatkan hubungan customer serta supplier dengan memberikan kualitas yang lebih baik dan memberikan pelayanan yang tepat waktu. Lean manufacturing memberikan strategi yang bervariasi untuk peningkatan kinerja dan meningkatkan daya saing dalam persaingan global

\section{Waste}

Waste dapat didefinisikan sebagai segala aktivitas kerja yang tidak memberikan nilai tambah dalam proses transformasi input menjadi output sepanjang value stream (Gaspersz \& Avanti, 2011). Menurut Hines dan Taylor (2000) ada tujuh tipe waste (seven waste) yang diidentifikasi sebagai berikut :

1. Over Production

2. Defect (Reject)

3. Uncessary Inventory

4. Inappropriate Processing

5. Excessive Transportation

6. Waiting/idle

7. Unncessary Motion

\section{Macam-macam Aktifitas}

Didalam proses produksi terdapat tiga tipe operasi yang didefinisikan menurut Hines Peter \& Rich, Nick (1997). Ketiga tipe operasi atau aktivitas adalah sebagai berikut :

1. Non-Value Adding (NVA)

2. Necessary but Non-Value Adding (NNVA)

3. Value Adding (VA)

\section{Value Stream Mapping (VSM)}

Value stream mapping (VSM) adalah alat yang efektif untuk praktik lean manufacturing. VSM mendekati seluruh aliran proses dalam metode tiga langkah di mana pertama memproduksi diagram yang menunjukkan aliran material dan informasi aktual atau Kondisi Saat Ini tentang bagaimana proses aktual beroperasi. Ini dibuat saat berjalan di jalur produksi. Kedua, peta Negara Masa Depan diproduksi untuk mengidentifikasi akar penyebab pemborosan dan melalui perbaikan proses yang dapat memberikan dampak finansial yang besar pada proses, aliran proses lean. Perbaikan ini kemudian dilakukan, Rencana Implementasi sebagai bagian dan rincian parsial dan tindakan yang diperlukan untuk mendapatkan tujuan proyek dalam proses kaizen 
(perbaikan berkelanjutan) dan poka-yoke (Rahani \& Muhammad Al-Ashraf, 2012).

\section{Big Picture Mapping}

Menurut Hines dan Taylor (2000), big picture mapping merupakan sebuah tool yang dikembangkan dari value stream mapping. Big picture mapping berfungsi untuk mengidentifikasi dimana terdapat waste, serta mengetahuigketerkaitan antara aliran informasi dan aliran material. Penggambaran aliran informasi dan aliran material dengan menggunakan big picture mapping dilakukan berdasarkan simbolsimbol. Penggambaran big picture mapping dilakukan dengan menerapkan lima fase penyusunan big picture mapping. Berikut merupakan penjelasan tiap fase yang dimaksudkan.Untuk melakukan pemetaan terdapat aliran informasi dan material atau produk secara fisik, langkah-langkah pertama yang harus dilakukan adalah sebagai berikut :

1. Mengidentifikasi jenis kebutuhan akan produk tersebut, kapasitas dan frekuensi pengirimannya, pemesanannya, serta jumlah persediaan yang disiapkan untuk keperluan customer.

2. Selanjutnya menggambarkan aliran informasi dari customer ke supplier

3. Menggambarkan aliran fisik yang berupa aliran material atau produk dalam perusahaan

4. Menghubungkan aliran onformasi dan aliran fisik dengan anah panah yang dapat berisi informasi jadwal yang digunakan, intruksi kapan pengiriman dan dimana biasanya terjadi masalah dalam aliran fisik.

\section{Value Stream Analysis Tools (Valsat)}

Menurut Hines \& Rich (1997) pada prinsipnya, value stream analysis tool digunakan sebagai alat bantu untuk memetakan secara detail aliran nilai (value stream) yang berfokus pada value adding process. Detail mapping ini kemudian dapat digunakan untuk menemukan penyebab waste yang terjadi. Terdapat 7 macam detail mapping tools yang paling umum digunakan yaitu process activity mapping, Supply Chain Response Matrix, Production Variety Funnel, Quality Filter Mapping, Demand Amplification Mapping, Decision Point Analysis serta Physical Structure.

1. Process Activity Mapping

2. Supply Chain Response Matrix

3. Production Variety Funnel

4. Quality Filter Mapping

5. Demand Amplification Mapping

6. Decision Point Analysis

7. Physical Structure

\section{Fisbone Diagram}

Diagram sebab-akibat atau dikenal dengan istilah "Diagram Tulang Ikan" (Fishbone Diagram), karena bentuknya seperti ikan atau dikenal juga dengan nama "Diagram Ishkawa" yang pertamakali diperkenalkan oleh prof. Kaouruu Isikawa dari Universitas Tokyo pada tahun 1953 (Gaspersz \& Avanti, 2011). Diagram sebab-akibat. Diagram ini digunakan untuk menunjukan faktorfaktor penyebab (sebab) dan karakteristik kualitas (akibat).

Diagram sebab-akibat juga digunakan untuk keperluan lainnya sebagai berikut :

1. Membantu mengidentifikasi akar permasalahan

2. Membantu mengembangkan ide untuk solusi dari suatu masalah

3. Membantu dalam menentukan fakta yang lebih lanjut

Contoh Cause And Effect Diagram

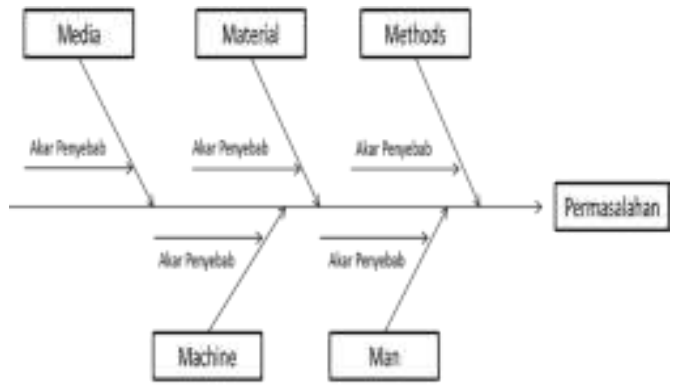

Gambar 1 Contoh Diagram Fishbone

(Cause And Effect Diagram)

FMEA (Failure Mode Effect Analysis) 
Vol. 1, No. 4, 2020

FMEA adalah suatu prosedur terstruktur untuk mengidentifikasi dan mencegah sebanyak mungkin mode kegagalan. Suatu mode kegagalan adalah apa saja yang termasuk dalam kecacatan atau kegagalan dalam desain, kondisi di luar batas spesifikasi yang telah ditetapkan atau perubahan pada produk yang menyebabkan terganggunya fungsi fungsi dari produk tersebut. Melalui menghilangnya mode kegagalan, diman FMEA akan meningkatkan keandalan dari produk dan pelayanan sehingga meningkatkan kepuasan konsumen akan produk atau pelayanan tersebut. FMEA digunakan untuk mengidentifikasi potensi kegagalan, efek yang ditimbulkan pada operasi dari produk dan mengidentifikasi aksi untuk mengatasi masalah tersebut (Badariah, dkk, 2016)

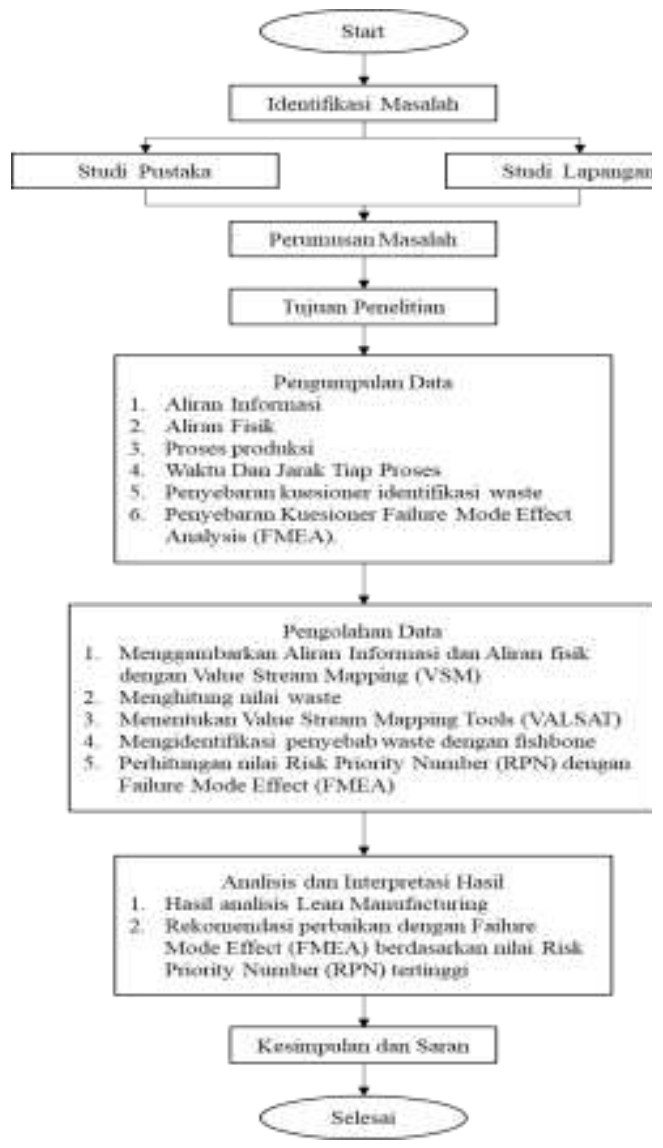

Gambar 2 Flowchart Penyelesaian Masalah

\section{HASIL DAN PEMBAHASAN}

Pembuatan Value Stream Mapping (VSM), Setelah didapatkan data mengenai aliran informasi, alian fisik, waktu aktivitas dan jarak pada tiap proses produksi kemudian data yang telah diperoleh digunakan untuk menggambarkan Current State Value Stream Mapping atau keadaan awal pada lantai produksi dalam pemenuhan order decking yang dapat dilihat pada gambar 4.3 dibawah ini. 
Vol. 1, No. 4, 2020

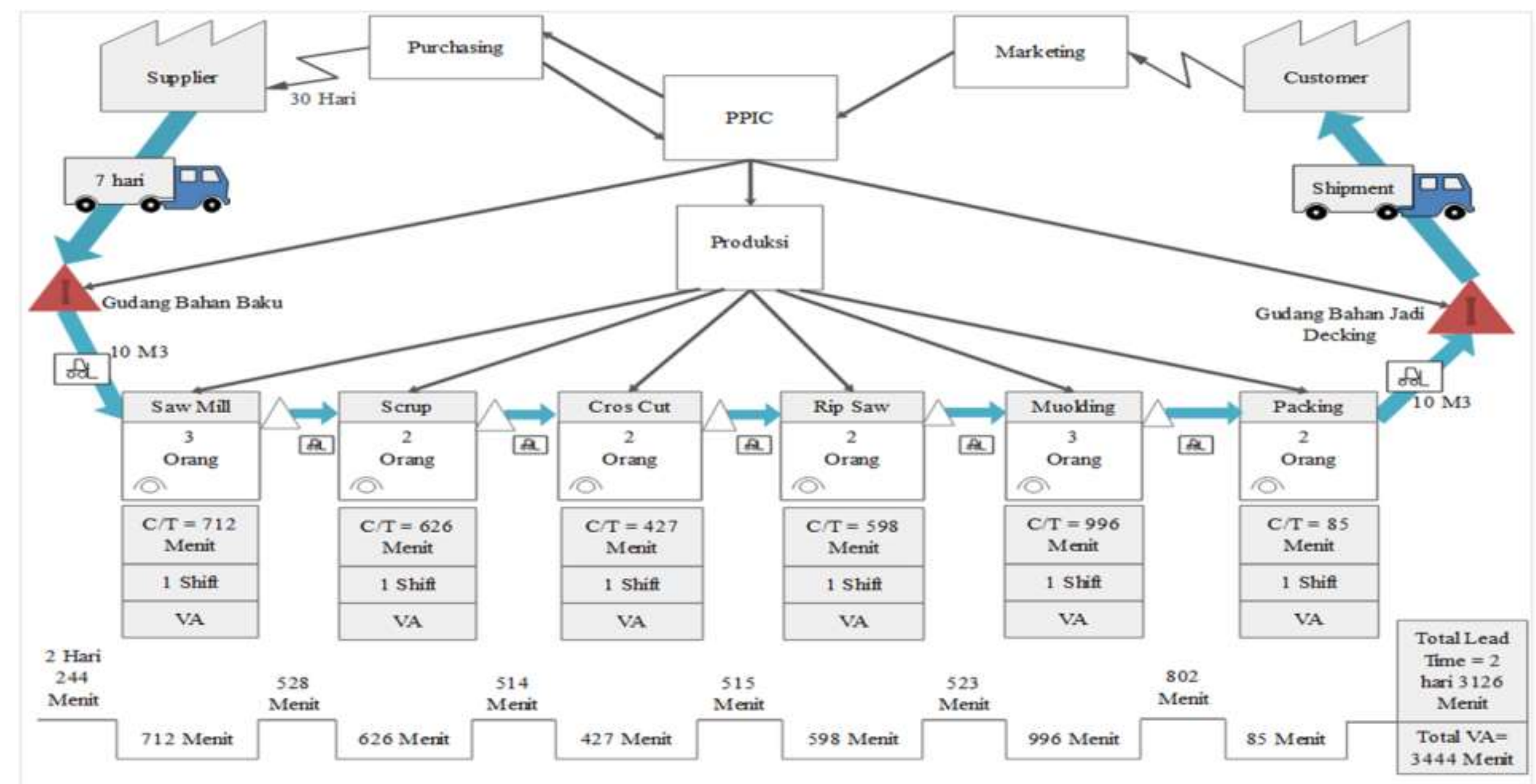

Gambar 3 Current State Value Stream Mapping Perusaahan Pengolahan Kayu di lamongan 


\section{Identifikasi Waste}

Setelah dilakukan penggrambaran Current State Value Stream Mapping dapat terlihat aliran indormasi dan aliran produksi decking. Dari penggambaran Current State Value Stream Mapping dan kuisioner yang telah disebarkan diperusahaan akan teridentifikasi pemborosan yang terjadi dilantai produksi decking. Berikut waste yang teridentifikasi dalam lantai produksi :

1. Defect

2. Unnecessary Inventory

3. Excessive Transportation

4. Waiting/idle

5. Unncessary Motion

Selain jenis waste yang ada diperusahaan dari kuisoner juga didapatkan bobot atau nilai dari masingmasing waste yang telah diberikan oleh masing-masing responden pada kuisioner yang bisa dilihat pada lampiran, berikut hasil rekap penialian responden terhadap bobot masing-masing waste pada tabel 6 Tabel 6 Rekap Hasil Kuisioner Identifikasi Waste

\begin{tabular}{|l|c|c|c|c|c|c|}
\hline \multirow{2}{*}{ Jenis Waste } & \multicolumn{5}{c|}{ Frekoensi } & \multirow{2}{*}{ Jumlah Responden } \\
\cline { 2 - 6 } & 1 & 2 & 3 & 4 & 5 & \\
\hline Orer Production & 10 & 0 & 0 & 0 & 0 & 10 \\
\hline Defect & 0 & 0 & 3 & 2 & 5 & 10 \\
\hline Uncesary Inrentory & 0 & 1 & 2 & 4 & 3 & 10 \\
\hline $\begin{array}{l}\text { Innappropriate } \\
\text { Processing }\end{array}$ & 10 & 0 & 0 & 0 & 0 & 10 \\
\hline $\begin{array}{l}\text { Excessive } \\
\text { Transportation }\end{array}$ & 1 & 3 & 2 & 2 & 2 & 10 \\
\hline Waiting & 1 & 2 & 2 & 3 & 2 & 10 \\
\hline unncessary Motion & 1 & 3 & 3 & 1 & 2 & 10 \\
\hline
\end{tabular}

\section{Value Stream Mapping Tools (VALSAT)}

Pemilihan Value Stream Mapping Tools (VALSAT) dilakukan dengan perkalian nilai rata-rata bobot masingmasing waste dari hasil kuisioner identifikasi waste dengan nilai tabel Value stream Mapping Tolls (VALSAT) untuk tiap jenis waste.

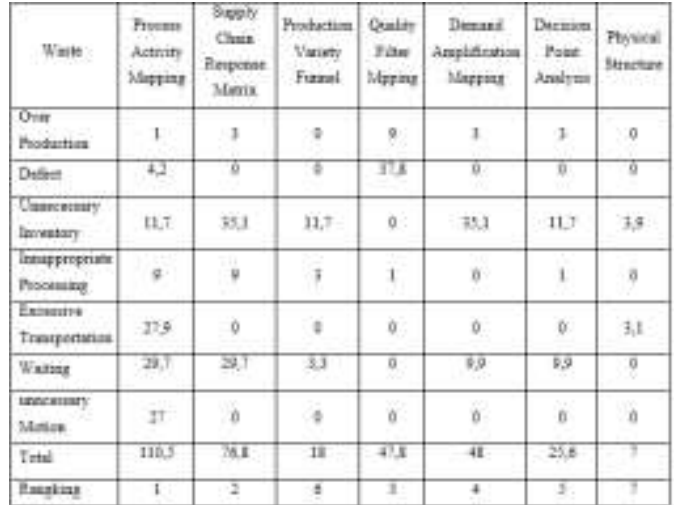

Tabel 7 Hasil Pembobotan Value Stram Mapping (VALSAT)

Dari tabel 7 didapatkan 3 tools yang memiliki bobot atau nilai paling tinggi dan akan digunakan yaitu :

1. Proses Activity Mapping (PAM)

2. Suplly Chain Respon Matrix (SCRM)

3. Quality Filter Mapping (QFP)

\section{Process Activity Mapping (PAM)}

Process Activity Mapping merupakan tools yang dipergunakan untuk mengidentifikasi aliran fisik dan aliran informasi di lantai produksi kayu decking. Dalam PAM nantinya akan ada penggolongan aktivitas menjadi 5 kategori yaitu, storage (S), transportation $(\mathrm{T})$, operation $(\mathrm{O})$, inspection (I) dan delay (D), yang akan memudahkan dalam identifikasi aktivitas. Berikut PAM untuk total produksi $10 \mathrm{M} 3$

Tabel 8 Perbandingan Kebutuhan Waktu Sebelum Dan sesudah

\begin{tabular}{|c|c|c|c|}
\hline Tipe Abtiritas & Sebelum & Sesudah & Tipe Altinitas \\
\hline Operasi (0) & 3444 Menit & 3444 Menit & Operasi (0) \\
\hline Transpostasi (T) & $52 \quad$ Menit & 977 Menit & Transportasi (T) \\
\hline Inspeksi (I) & 284 Menit & 284 Menit & Inspeksi (I) \\
\hline Storage (S) & 2550 Manit & 1020 Menit & Stocrage (S) \\
\hline Delay (D) & 240 Memit & 240 Menit & Delay (D) \\
\hline Total & 6570 Menit & 5985 Menit & Total \\
\hline
\end{tabular}

\section{Pengelompokan}

\section{Berdasarkan Jenis Aktivitas}

Aktivitas yang ada dalam proses produksi dapat dikategorikan menjadi tiga kategori, yaitu aktivitas yang bernilai tambah atau value added (VA) dimana merupakan aktivitas yang penting dalam 
Vol. 1, No. 4, 2020

proses produksi, aktivitas yang tidak bernilai tambah atau non-value added (NVA) dimana tidak bernilai tambah dan bisa dihilangkan jika memang tidak diperlukan, dan aktivitas yang tidak bernilai tambah tetapi diperlukan dalam proses produksi atau necessary non-value added (NNVA).

Tabel 9 Pengelompokan Jenis Aktivitas pada proses produksi

\begin{tabular}{|c|l|c|c|c|}
\hline No & Altivitas & VA & NVA & NNVA \\
\hline 1. & Set-up semua mesin & & & $\checkmark$ \\
\hline 2. & Pemindahan bahan baku ke mesin SawMill & & & $\checkmark$ \\
\hline 3. & Proses dalam mesin SawMill & $\checkmark$ & & \\
\hline 4. & Penataan Output SawMill dalam pallet & & & $\checkmark$ \\
\hline 5. & Pemindahan ke proses Scrap & & & $\checkmark$ \\
\hline 6. & Proses scrap & $\checkmark$ & & \\
\hline 7. & Penataan output scrap dalam palet & & & $\checkmark$ \\
\hline 8. & $\begin{array}{l}\text { Pemindahan bahan dari mesin scrap ke } \\
\text { mesin cros cut }\end{array}$ & & & $\checkmark$ \\
\hline 9. & Proses cros cut & $\checkmark$ & & \\
\hline 10. & Penataan output mesin cros cut & & & $\checkmark$ \\
\hline 11. & Pemindahan bahan ke mesin Rip Saw & & & $\checkmark$ \\
\hline 12. & Proses Rip Saw & $\checkmark$ & & \\
\hline 13. & Penataan output Rip Saw & & & $\checkmark$ \\
\hline 14. & Pemindahan bahan baku ke mesin moulding & & & $\checkmark$ \\
\hline 15. & Proses mesin moulding & $\checkmark$ & & \\
\hline 16. & QC Output Mesin Moulding & & & $\checkmark$ \\
\hline 17. & Penataan Output Mesin Moulding & & & $\checkmark$ \\
\hline
\end{tabular}

\section{Quality Filter Mapping (QFM)}

Pada tahap ini akan dijadikan sebagai evaluasi waste defect jenis rework dikarenakan seperti dijelaskan pada bab 1 waste ini adalah waste yang memiliki persentase paling besar dan diatas batas toleransi perusahaan sebesar $15 \%$ seperti yang dapat dilihat pada tabel 10 dibawah ini

Tabel 10 Persentase Jumlah Defect

\begin{tabular}{|c|c|c|c|c|c|c|}
\hline \multirow{2}{*}{ No } & \multirow{2}{*}{ Bulan-Tatun } & \multirow{2}{*}{ Toul Prodts: } & \multicolumn{4}{|c|}{ Jenis defect } \\
\hline & & & rexvork & $\%$ & Rejeat & 8 \\
\hline 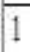 & Nor - 2018 & 36,8814 & 13,0669 & $35 \%$ & 0,2845 & 13,3714 \\
\hline $1^{2}$ & Des - 2018 & 14,8830 & 6,7430 & $45 \%$ & 0,3379 & 7,082 \\
\hline 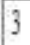 & Jan- 2019 & 69,8044 & 10,4116 & $15 \%$ & 0,9282 & 11,3398 \\
\hline 4 & $\mathrm{Feb}-2019$ & 40459 & 6.1194 & $14 \%$ & 0,055 & 6.1549 \\
\hline
\end{tabular}

Sumber ; Data Perusaahan Pengolahan Kayu)

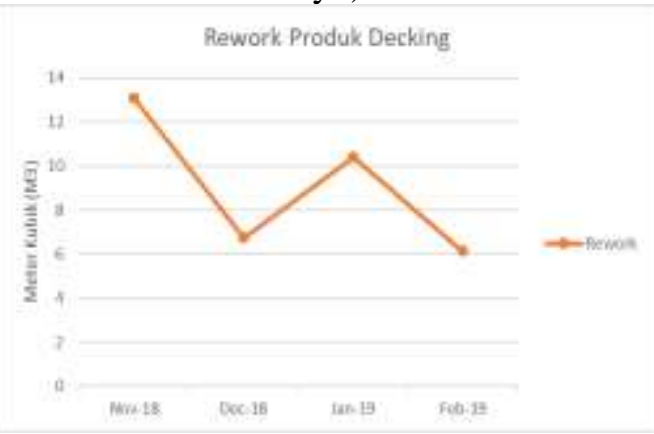

Gambar 4 Grafik Defect Rework

Besarnya persentase rework diperusahaan akan dijadikan sebagai pertimbangan untuk dilakukan dan perbaikan dengan analisa terlebih dahulu mengenai sebab dari waste rewok tersebut dengan diagram sebab akibat (Fish Bone Diagram)

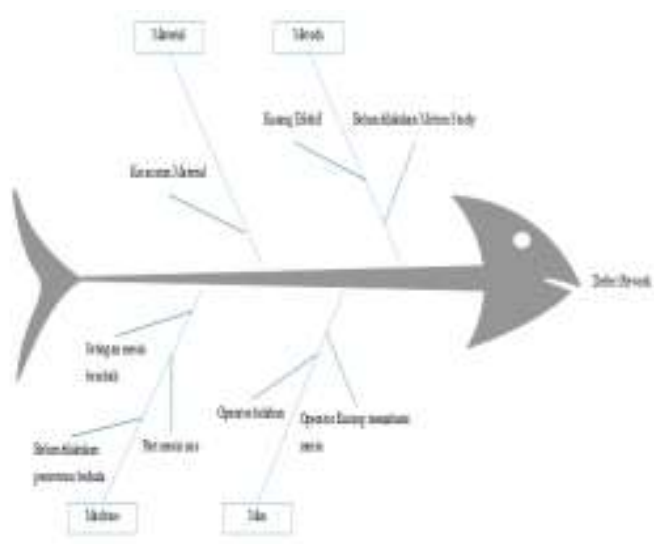

Gambar 5 Fish Bone Diagram Defect jenis Rework

\section{Supply Chain Respon Matrix}

Supply Chain Respon Matrix (SCRM) berfungi mengetahui adanya peningkatan maupun penurunan tingkat persediaan pada waktu distribusi pada tiap area supply chain days phisical stock 
merupakan rata-rata perhari lama waktu material berada dalam sistem pemenuhan order. Perhitungan days Phisical Stock didapat dari kapasitas mesin atau area dibagi dengan supply atau bahan yang diterima oleh mesin atau area tersebut. Dalam proses produksikayu decking memiliki 7 area dengan urutan sebagai berikut (1) area gudang material, (2) area saw mill, (3) area scrap, (4) area rip saw, (5) area cros cut, (6) area moulding dan (7) area gudang bahan jadi yang sekaligus area packing produk decking.

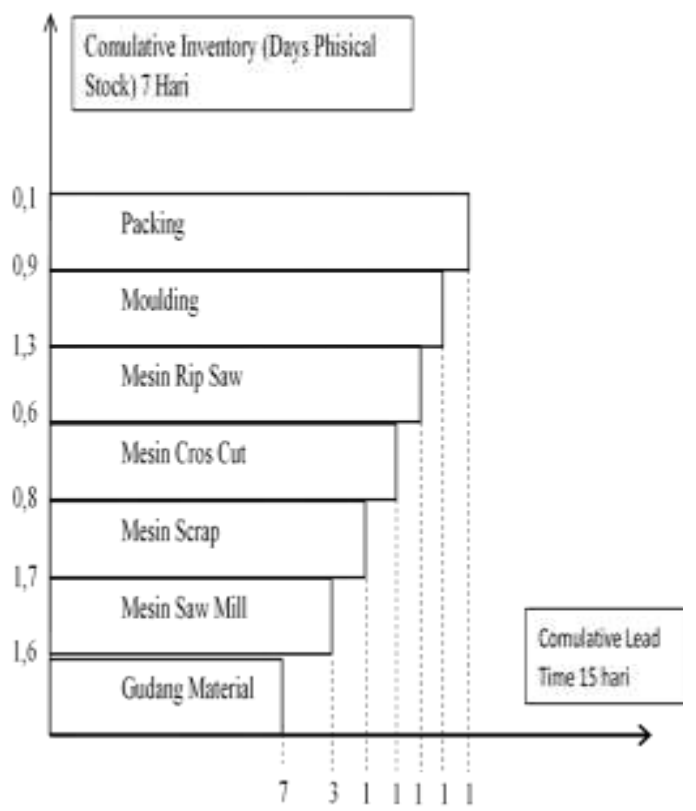

Gambar 6 Usulan Perbaikan Supply Chain Response Matrix proses produksi Decking Dapat diihat pada tabel 4.8 penghematan waktu yang terjadi sesudah usulan perbaikan pada area decking sehingga days physical stock 0,9 yang sebelumnya 1,7 dengan lead time yang masih sama yaitu 15 Hari.

\section{Failure Mode and Effect Analysis (FMEA)}

Setelah dilakukan pemilihan dan pengolahan data dengan tolls melalui Valsat dilanjutkan dengan mencari mode kegagalan tiap waste dengan Failure Mode And Effect Analysis (FMEA). Pencarian Mode Kagagalan dilakukan melalui kuisioner yang disebarkan diperusahaan, hasil kuisoner mengenai mode kegagalan dapat dilihat pada lampiran. Setelah mode kegagalan didapat selanjutnya mencari RPN (Risk Prioriyty Number) dari tiap mode kegagalan terhadap tiap waste, Nilai RPN didapatkan dari kuisioner dan diskusi dengan responden diperusahaan yang dapat dilihat pada lampiran. Dalam menentukan nilai RPN terdapat kriteria Penialian Tingkat Keparahan (Severity), Keterjadian (Occurance) dan Deteksi (Detection) dengan masing-masing kriteria memiliki rentang penilaian 1-10.

Nilai RPN yang didapat kemudian dipilih mana potensial cause (penyebab potensial), alat kontrol dan efek yang ditimbulkan dengan nilai paling tinggi untuk dijadikan rekomendasi agar segera dilakukan tindakan perbaikan. Pencarian mode kegagalan dan nilai RPN berdasarkan kuisioner dan diskusi terhadap pihak terkait di perusahaan yaitu, kepada Kabag PPIC, Kadept Produksi, Kabag Maintenance, Kabag Gudang, Finishing \& Packing, Oprerator Moulding, Operator Scrap , Administrasi Produksi, sekretaris system, Kabag Expor yang berhubungan langsung dengan area produksi, jadi untuk total responden yang diberikan kuesioner sebanyak 10 orang. Berikut hasil rekap hasil Nilai RPN yang dapat dilihat Pada tabel dibawah ini : 
Tabel 11 Failure Mode And Effect (FMEA)

\begin{tabular}{|c|c|c|c|c|c|c|c|}
\hline $\begin{array}{l}\text { Mode Kegagalan } \\
\text { (Failure Mode) }\end{array}$ & $\begin{array}{c}\text { Efek Kegagalan (efffect of } \\
\text { Failure) }\end{array}$ & $\mathrm{S}$ & $\begin{array}{c}\text { Penyebab Kegagalan (Cause } \\
\text { Of Failure) }\end{array}$ & $\mathrm{O}$ & Penanganan (Control) & D & $\mathrm{RPN}$ \\
\hline \multirow{3}{*}{ waitting } & $\begin{array}{l}\text { Proses Berikutnya atau } \\
\text { sebelumnya terganggu }\end{array}$ & 8 & Trouble Pada Mesin & 8 & $\begin{array}{l}\text { Perawatan berkala } \\
\text { (Preventif) }\end{array}$ & 5 & 320 \\
\hline & perpindahan material terhambat & 7 & $\begin{array}{c}\text { Perelatan Delivery Belum } \\
\text { Komplit }\end{array}$ & 9 & $\begin{array}{c}\text { Penambahan Jumlah } \\
\text { Forklif }\end{array}$ & 3 & 189 \\
\hline & mesin Berhenti Beroprasi & 6 & Kurangnya Operator & 6 & Penambahan Operator & 4 & 144 \\
\hline \multirow[t]{2}{*}{ Defect } & $\begin{array}{c}\text { Unncessary Inventory dan } \\
\text { Biaya rework }\end{array}$ & 8 & $\begin{array}{l}\text { Defect Rework } \\
\text { (Panjang/Lebar) }\end{array}$ & 9 & $\begin{array}{c}\text { Pembekalan Operator } \\
\text { (Breafing) \& } \\
\text { Monitoring }\end{array}$ & 5 & 360 \\
\hline & Penurunan laba perusahaan & 6 & $\begin{array}{c}\text { Defect reject } \\
\text { (Patah,Retak,Goresan) }\end{array}$ & 9 & $\begin{array}{l}\text { QC bahan baku, Batas } \\
\text { Penumpukan material }\end{array}$ & 4 & 216 \\
\hline $\begin{array}{l}\text { Unnsessary } \\
\text { Inventory }\end{array}$ & $\begin{array}{l}\text { Harga jual produk menurun, } \\
\text { biaya simpan }\end{array}$ & 7 & $\begin{array}{c}\text { Terjadinya Defect rework } \\
\text { yang tidak langsung diproses } \\
\text { dan reject }\end{array}$ & 8 & $\begin{array}{l}\text { Pengolahan defect } \\
\text { rework se segera } \\
\text { mungkin }\end{array}$ & 4 & 224 \\
\hline \multirow{2}{*}{ Unnsessary Motion } & $\begin{array}{c}\text { Peluang terjadinya defect } \\
\text { rework }\end{array}$ & 7 & $\begin{array}{c}\text { Penarikan material terlalu } \\
\text { cepat pada saat proses }\end{array}$ & 8 & Kaizen activity & 5 & 280 \\
\hline & $\begin{array}{l}\text { Belum adanya pengukuran } \\
\text { beban kerja (Motion Study) }\end{array}$ & 7 & Operator Kelelahan & 7 & $\begin{array}{c}\text { Melakukan Motion } \\
\text { Study }\end{array}$ & 3 & 147 \\
\hline \multirow[b]{2}{*}{$\begin{array}{c}\text { Excessive } \\
\text { Transportation }\end{array}$} & $\begin{array}{c}\text { waktu transportasi yang lama } \\
\text { dan berulang ulang }\end{array}$ & 9 & $\begin{array}{c}\text { Jarak Antar Mesin Terlalu } \\
\text { jauh }\end{array}$ & 9 & $\begin{array}{l}\text { Penataan Ulang tata } \\
\text { letak }\end{array}$ & 5 & 405 \\
\hline & $\begin{array}{l}\text { Peningkatan Biaya transportasi } \\
\text { untuk kembali ke proses rework }\end{array}$ & 8 & $\begin{array}{c}\text { Tingginya prosesntase } \\
\text { Defect }\end{array}$ & 8 & $\begin{array}{c}\text { Penurunan Jumlah } \\
\text { defect pengecekan set- } \\
\text { up mesin }\end{array}$ & 4 & 256 \\
\hline
\end{tabular}


Gambar 7 Future Sate Value Stream Mapping

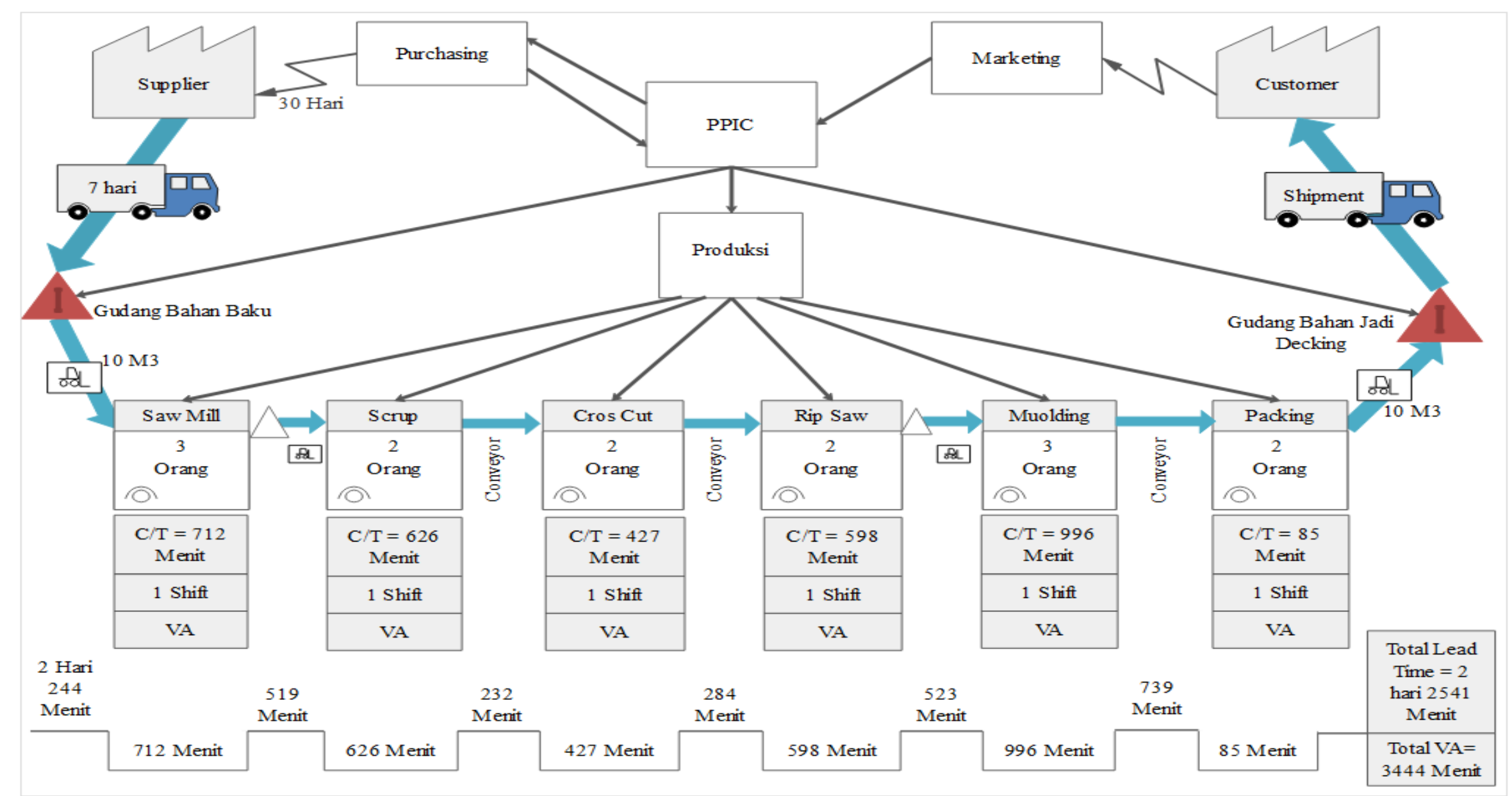




\section{Kesimpulan}

Kesimpulan yang dapat diambil berdasarkan pengolahan data dan analisa yang telah dilakukan adalah sebagai berikut :

1. Dari idemtifikasi waste yang telah dilakukan diperusahaan didapatkan waste yang terjadi diperusahaan beserta bobot masing-masing waste. Waste defect dengan bobot 4,2, Waste Unnsesary Inventory dengan bobot 3.9, waste waitting dengan bobot 3,3, Waste Excessive Trsnsportation dengan bobot 3,1 dan unncesary motion dengan bobot 3

2. Dari identifikasi keadaan awal dengan curent value stream mapping di lantai produksi decking dapat dilihat pada gambar 4.2 terlihat waktu tunggu pemesanan material bahan baku decking selama 30 Hari dengan pengiriman tiap 1 minggu sekali. Adapun lead time pengiriman material dari gudang bahan baku ke area produksi mesin saw mill selama 2 hari 224 menit. Dan waktu proses dari input material $10 \mathrm{M} 3$ sampai menjadi produk decking dan dipacking sebesar 3444 menit.

3. Hasil pengolahan data kuisioner bobot masing-masing waste yang dikalikan dengan bobot pada Value Stream Mapping Tools (VALSAT) didapatkan 3 tolls yang terpilihin yaitu : Process Activity Mapping (PAM), Supply Chain Response Matrix (SCRM), dan Quality Filter Mapping (QFM)

4. Usulan Perbaikan dengan Failure Mode And Effect Analysis (FMEA) didapatkan dari Nilai Risk Priority Number (RPN) tertinggi dari masingmasing mode terhadap masingmasing wate diantaranya : Waste Waitting dengan nilai RPN 320 "Trouble Pada Mesin yang mengakibatkan proses sebelum atau berikutnya terganggu" maka usulan perbaikannya aldalah melakukan prefentif maintenance untuk meminimalisir kemungkinan terjadinya kejadian yang sama. Waste defect dengan nilai RPN 360 “
"Rework" maka usulan perbaikan pembekalan pada operator dan monitoring selama proses produksi. Waste Unsessary Inventory dengan nilai RPN 224 " terjadinya unnsessary inventory akibat rework yang tidak langsung diproses" maka usulan perbaikannya adalah segera merework produk yang harus di rework sehingga tidak semakin menumpuk. Waste unssessary Motion dengan nilai RPN 280 "Penarikan material terlalu cepat pada saat proses" maka usulan perbaikan perusahaan menerapkan kaizen activity. Waste excessive Transportation dengan nilai RPN 405 "Jarak antara mesin terlalu jauh" maka usulan yang dilakukan penataan tata ulang tata letak sehingga jarak transportasi berkurang.

\section{Saran}

Adapun saran yang dapat diberikan dalam penelitiian ini yaitu :

1. Bagi Perusahaan :

Perusahaan dapat meningkatkan efektifitas dan performa perushaan dengan meminmalkan waste yang ada berdasarkan hasil penelitian dengan metode lean manufacturing.

2. Bagi peneliti selanjutnya :

- Peneliti selanjutnya dapat memakai hasil dari penelitian ini sebagai perbandingan dengan hasil penelitiian yang dilakukan dengan objek dan tenpat penelitian yang sama.

- Peneliti selanjutnya dapat melakukan analisis yang lebih baik lagi degan tools yang belum digunakan dalam penelitian ini.

\section{Daftar Pustaka}

[BPS] Badan Pusat Statistik. 2018. Pertumbuhan Produksi IBS Tahun 2018 Naik 4,07 Persen dibandingkan tahun 2017. https://www.bps.go.id/. Diakses pada 22 Maret 2019. 
Badariah, Nurlailah, Dedy Sugiarto, dan Chani Anugerah. 2016. Penerapan Metode Failure Mode and Effect Analysis (FMEA) dan Expert System (Sistem Pakar). Jurnal Fakultas Teknologi Industri Universitas Trisakti Jakarta p-ISSN:2407-1846.

Carreira, Bill. 2005. Lean Manufacturing That Work. New York: American Management Association (AMACOM).

Daonil, 2012. Implementasi Lean Manufacturing untuk Eliminasi Waste pada Lini Produksi Machining Cast Wheel dengan Menggunakan Metode WAM dan VAISAT. Tesis. Teknik Industri Universitas Indonesia Depok.

Feld, William M. 2001. Lean Manufacturing: Tools, Techniques, and Ho To Use Them. Florida: St. Lucie Press.

Gaspersz, Vincent dan Avanti Fontana. 2011. Lean Six Sigma for Manufacturing and Service Industries. : Vinchristo Publication.

Hines, P., dan D. Taylor. 2000. Going Lean. Cardiff, UK: Lean Enterprise Research Center Cardiff Business School.

Hines, P., and Nick Rich. 1997. The Seven Value Stream Mapping Tools International Journal of Operation \& Production Management, Vol. 17, No. 1, pp. 46-04 Cardift, UK: Lean Enterprise Research Centre, Cardiff Business School.

[Kemendag] Kementrian Perdagangan. 2019. Perkembangan Ekspor Non Migas (Sektor) Periode: 20142019.

http://www.kemendag.go.id/. Diakses pada 22 Maret 2019.
Khairunnas, Jefri. 2016. Meminimasi Lead Time Produksi Menggunakan Pendekatan Lean Manufacturing di PT Indofarma (Persero) (Studi Kasus Kapsul Piroxicam 20 $\mathrm{Mg}$ ). Artikel Teknik Industri Universitas Islam Bandung.

Modi, Denish B., dan Hemant Thakkar. 2014. Lean Thinking: Reduction of Waste, Lead Time, Cost through Lean Manufacturing Tools and Technique. International Journal of Emerging Technology and Advanced Engineering, Vol. 4 No. 3, ISSN 2250-2459, ISO 9001:2008.

Nuruddin, A.W, Surachman, Nasir Widha Setyanto, dan Rudy Soenoko. 2013. Implementasi Konsep Lean Manufacturing untuk Meminimalkan Waktu Keterlambatan Penyelesaian Produk "A" Sebagai Value Pelanggan. Studi Kasus PT TSW (Tuban Steel Work). Jurnal Rekaya Mesin Vol. 4, No. 2, 147-156 ISSN 0216$468 X$.

Parsana, T. S., \& Patel, T. M. 2014. A Case Study: A Process FMEA Tool to Enhance Quality and Efficiency of Manufacturing Industry. Bonfring International Journal of Industrial Engineering Management, Vol. 4 No. 3, ISSN 2277-5056.

Rahani \& Muhammad Al-Ashraf. 2012. Production Flow Production Flow Analysis through Value Stream Mapping: A Lean Manufacturing Process Case Study. Malaysia: Elsevier Ltd. 
Rahmiyarno, Ardiansah. 2013. 5-9.

Penerapan

Manufacturing

Mengidentifikasi

Lean

untuk

dan

Minimasi Waste Produksi

Benang Polyster pada Mesin

Carding dan Mesin Drawing.

Studi kasus di Departemen

Produksi PT X Kabupaten

Sleman DI Yogyakarta. Jurnal

Teknik Industri, Fakultas Sains

dan Teknologi. Universitas

Islam Negeri Sunan Kalijaga.

Yogyakarta Vol. 5 No. 2,

2301-ISSN:2337-3539.

Ristyowati, Trismi, Ahmad Muhsin, dan Putri Puji Nuraini, 2012.

Minimasi Waste pada

Aktivitas

Hidayat, H., Jufriyanto, M., \& Rizqi,

A. (2021). Perancangan RCM

(Reliability Centered

Maintenance) Untuk Mengurangi

Downtime Mesin Pembuat Botol

(Studi Kasus PT IGLAS

(Persero), Gresik). MATRIK :

Jurnal Manajemen Dan Teknik

Industri Produksi, 21(2), 157 -

164.

doi:10.30587/matrik.v21i2.2038

Hidayat, H. (2020). Application of the EOQ (Economic Order Quantity)

Method in Determining Chemical Supplies in PT. Semen Indonesia. International Journal of Science, Engineering and Information

Technology, 5(1), 226-230.

Hidayat, Jufriyanto, M., Wasiur, A., \& Ningtyas, A. H. P. (2020).

Analysis Of Load Variations On ST 60 Steel Using Vickers

Method. International Journal of

Science, Engineering and Information Technology, 05(02), https://doi.org/10.21107/ijseit.v5i

1.8940 